\title{
Metafunctional Practices in Medical Research Articles: A Comparative Study
}

\author{
Nader Assadi ${ }^{1}$, Mojtaba Ghassemi ${ }^{1}$ \& Alireza Madadi ${ }^{1}$ \\ ${ }^{1}$ English Language and Literature Dept., Islamic Azad University of Ahar, Ahar, Iran \\ Correspondence: Mojtaba Ghassemi, English Language and Literature Dept., Islamic Azad University of Ahar, \\ Ahar, Iran. Tel: 989-127-543-063. E-mail: Ma.Qassemi@gmail.com
}

Received: April 17, 2014 Accepted: May 6, 2014 Online Published: June 13, 2014

doi:10.5539/elt.v7n7p49 URL: http://dx.doi.org/10.5539/elt.v7n7p49

\begin{abstract}
The purpose of this study is to explore any possible difference among the verb types chosen in articles written in English by the non-natives and natives. In so doing, Halliday's Systemic Functional Grammar (1994) was employed. 80published articles from the medical sciences field of study were chosen from among which40were written by native English writers and 40 by the non-natives. In the light of the guidelines on Experiential Metafunctions, the articles were analyzed. Then the Frequency of each common type of verb was computed. Having applied Chi-Square, the researchers found out that the native English speakers and non-native ones employ different types of verbs. According to the results, non-native English language researchers may introduce the types of the verbs based on their L1 norms. Finally it seems necessary for Language Teachers and ESP Materials developers to take into account such differences while teaching and adapting writing materials.
\end{abstract}

Keywords: ESP, systemic functional grammar, halliday, experiential metafunction

\section{Introduction}

Scientific writing is a topic of much concern these days. Writing a research paper is a guaranteed way to share the scientific ideas, achievements and more importantly to join a scientific discourse community. Although there is a bulk of research articles written annually, not all non-native English writers can get their papers published in any international peer-reviewed journals.It may stem from different factors including deploying appropriate discourse standards, etc. Finding out these standards is the task undertaken in Discourse analysis.

In Discourse Analysis, it is argued that "Language is always used for specific purposes" (Jones, 2005, p. 5). In other words, Language, as discussed by Halliday (1994), is meaning potentials. Such potentiality is due to the number of options available to language producers. As the results, language is considered as a system of choices. And the linguists explore the relevance of the range of these choices (Chomsky, 1972, 1988; Givon, 1995; Halliday, 1994). The degree of relevance of the choices made is determined in relation to the social aspects. In nutshell, language producers are constantly choosing the appropriate language based on social effect(s) which the language producers try to make. The relationship between language and the social aspects us best described by M. Bloor and T. Bloor (1995, p. 9):

1) Language is used to Organize, Understand and Express our perceptions of the world and of own consciousness.

2) Language is used to enable us to participate in communicative acts with other people, to talk on roles and to express and understand feelings, attitude and judgments.

3) Language is used to relate what is said (or written) to the real world and to other linguistic events.

These are all referred to as functions of language. In a better sense, these functions vary in different contexts of situation. Thus language choices are made based on the functions best match the context of situations. Halliday distinguishes two types of functions of language. He referred to these functions as Macrofunctions and Metafunctions (1994, 2003).

Since metafunctions are dealing with social aspects of the language, linguists have tried to provide a comprehensive definition. "Metafunction ... realizes particular dimensions of social context" (Dunmire, 2008, p. 86). Thus, it can be argued that the intended meanings are only inferred as the result of choosing appropriate 
language. In so doing, language producers are required to be sensitive to the functions of language in general and metafunctions in particular. In a better sense, since metafunctions are touching different aspects of the world, while interpreting a clause or a sentence, only the meanings implied by metafunctions come to the mind(Bilal, 2012; Halliday, 1994). Therefore, it can be inferred that there should be some layers through which the meaning can be inferred. Pandian and Assadi (2010) discuss that there are three layers of meaning in ay clause.

These three layers can be discussed in the light of metafunctional processes. Metafunctions include textual, , interpersonal, and ideational (Halliday, 1994). Textual process is within the text. In other words, textual process refers to the relationship between the clauses in a given text. Through this process, the order of information in a clause is regulated. Technically speaking, textual process is the way the clauses interact with each other within the text. In a better sense, it determines the way that the intended information is organized (Dunmire, 2008; Halliday \& Matthiessen, 2004; Pandian \& Assadi, 2010). On the other hand, interpersonal process deals with the interlocutors communicate. Here the way that both parties exchange information and interact is analyzed. Such an analysis has revealed that interpersonal process involves giving and demanding. Thus the interlocutors play the role of either information giver or commodities demander (Halliday \& Matthiessen, 2004; J. Martin, 1992). The interlocutors play these two roles because interaction is the way that interpersonal meaning realizes.

The experiential metafunction, alternatively, deals with the nature of the relationship between language function(s) and social aspects. That is to say, the experiential metafunction reflects material, mental and relational processes (Halliday, 1994; Halliday \& Matthiessen, 2004; Pandian \& Assadi, 2010). Where the process handles the events, it is referred to as a material process. Technically speaking, material process involves acting on and happening (Martin, 1992). In other words, it, as Pandian and Assadi (2010) argue, is referring to "the doings and happenings of physical actions in the external world" (p. 29). Conversely, mental process is the representation of psychological events. Unlike the mental process which deals with the external world, mental one involves the verbal groups including "cognition, perception, emotion, and desideration" (Pandian \& Assadi, 2010 , p. 30). One the last process distinguished is relational one. It highlights the relationships between two concepts. In other words, it is "the process of being and having" (Halliday \& Matthiessen, 2004, p. 210).

\subsection{Problem Statement}

The aforesaid metafunctions deals with different aspects of the world. Hence, they try to disclose different modes of meaning hidden in different layers of the clauses. According to Jalilfar (2010), it is through experiential metafunctions that non-native speakers can meet publishers' criterion, and consequently increase the chance of getting their paper written in English published. In other words, the experiential metafunctions are considered as factors other than knowing the research methodologywhich can play a crucial role in successfully publishing a scholarly article. So it is not surprising that scholars believe writing a research article in English is a very challenging task for non-native speakers. And failure of getting a written article published is relatively high even though the researcher may strictly adopt an appropriate research method (Connor, 1996; Kanoksilapatham, 2007; Martin, 2003).

Empirically, such a study may add to our understanding of the process of writing scholarly articles in English. The findings will hopefully be of value to teachers, ESP materials developers, and even EFL learners. Only that the researchers whose first languages are not English can improve their research skills and consequently increase their chance of getting their scholarly works published. Bearing it in mind, few researchers have conducted some studies to distinguish the important factors playing role in writing research papers as well as ESP contexts while deploying Systemic Functional Grammar (SFG).

\subsection{Literature Review}

Exploring metafunctions and explaining their roles in EFL as well as ESP contexts are still subjects of many studies. Bumela (2013), in his study, touches the role of metafunctions in text comprehension. The results show that reading comprehension is affected by students' ability to distinguish the metafunctions in the assigned text.

Questing after determining factors playing role in successfully getting the articles written by non-native English writers in international scientific journals, Talebzadeh, Arabi, Taki, and Akhlaghi (2012) applied Hallidayan approach. To this end, they performed a functional analysis. Through determining verb tense, personal pronouns, and voice, they tried to explore the role of metafunctions. Their findings show that rhetorical structures of the abstracts written by non-native speakers are different from those of the native ones.

Helan and Jitka (2012) worked on the genre analysis of medical case report. Medical case report includes oral case presentation, written case histories and published case report. Doing so, they used Fleischman's (2003) category referred to as subjective, objective, assessment, and plan. They finally argue that there is a difference in 
structural organization in method and result sections as they compared their findings with those of the study done by Nwogu (1997).

Jalilfar (2010), in a study, asserts that the status of the theme varies in different languages. In other words, the usage of theme might be culture bound. To verify his hypothesis, he explored the articles in applied linguistics while deploying SFG. Having compared 32 articles published in the journals of ELT and Roshd, he concluded that there is a difference in the number and usage of thematic progression.

Finally, Fuzer and Barros (2009), in another study, tried to find out the role of ideational metafunctions. Having employed the model proposed by Halliday and Matthiessen (2004), they studied the functioning and technicalities of legal language in Brazilian context. They analyzed the text from ideational perspective in four sections: elaboration of accusation, the production of the proof, the defense, and the public accusation. To this end, they tried to investigate the texts' multivariate perspective. Based on the findings, they argue that social actors are very important in judicial proceedings.

\subsection{Research Question}

Medical papers are not exceptions to the rule. Their writers would get only a chance to join the medical discourse community and disseminate their achievements through getting the papers published. Based on such an assumption, the present study was developed to investigate whether or not there is any difference in the common types of verbs chosen in the scholarly medical articles written in English by native-speaker researchers and Iranian ones. This directive tries to touch the role of experiential metafunctions in research article writing, lacking which seems to be the main reason for the failure of many non-native English writers to publish their works in international scientific journals (Connor, 1996). Encountering such a problem, some studies are required to be conducted to deepen our understanding of the nature of experiential metafunctions in different fields of studies and genres of the professional texts (ESP) while adopting Hallidayan approach (Chakorn, 2006, 2007, 2011; Pishghadam, 2010).

\section{Methodology}

This study investigates whether or not there is any possible difference among the verbs chosen in the articles written in English by the native speakers and the non-native ones.

\subsection{Selection of Materials}

For the purpose of this study, articles for analysis were selected from electronic archive, http://ijms.sums.ac.ir/index.php/IJMS andhttp://msrj.chm.msu.eduin April 2014. Both journals are indexed by Indexed Copernicus International. In total, 80articles, 40 articles from each, were retrieved from the latest issues of both journals which have been published since 2010. The selection was based on simple sampling as the number of articles accessible through the archive of these journals was more than 40 .

Moreover, since there are a wide variety of submissions included in these journals, only the original articles were selected. Other submissions including reviews, commentaries, etc. were all excluded. In addition, though applying the simple sampling method, all articles in each journal have equal probability of selection.

\subsection{Procedure}

To carry out the present study, the pattern of experiential metafunctions was analyzed. In so doing, From among FG models, that of Halliday's (1994) is adopted because it seems more practical in investigating language from functional perspective. In so doing, all the verbs used by the researchers were counted and categorized under the headings of material, mental, and relational. Then to summarize the data collected, the verb types are presented in the table of frequency (table 4). Furthermore, a more detailed analysis was carried out. It was done to map the pattern of verb types applied to each group of data. Through running Chi-Square, the researchers expected to recognize any significant differences existing between both groups. The "P" value, in the performed comparison, was obtained by Chi-Square.

\section{Results and Discussion}

To find out if there is any significant difference between the two groups regarding the usage of the verb types,

The types of the verbs chosen by non-native English speakers and the native ones categorized. The summary of the some of the main types of the verbs are shown in table 1 and 2. 
Table 1. Some main common verb types chosen by the non-native English speakers

\begin{tabular}{ll}
\hline Types of the verbs & Examples \\
\hline Material & Perform; measure; incubate; etc. \\
Material & Understand; consider; etc. \\
Relational & Come; to be; express; comprise; become; etc. \\
\hline
\end{tabular}

As an example, in the methodology part, one of the non-native English speakers chooses relational verb type to describe the procedure.

The samples were (bolded by the researchers) in monoclonal anti-LH/FSH/estrogen/progesterone antibody...

Or in another article, the researchers describe the process as follow:

Gene expression was (bolded by the researchers) based on the 2-4Ct method in each condition (following formula).

In another article, the authors argue:

Any nucleolus came (bolded by the researchers) into maximal focus within the next traveling $5 \mu$ m optical section.

Table 2. Some main common verb types chosen by the native English speakers

\begin{tabular}{ll}
\hline Types of the verbs & Examples \\
\hline Material & survey; measure; perform; compared; examined; calculate; etc. \\
Material & Understand; surprise; recognize; etc. \\
Relational & To be; express; become; etc. \\
\hline
\end{tabular}

In the methodology part, the native English researchers describe the process as follow:

Symptoms for which respondents were 'unsure' were combined with 'incorrect' responses to assess for unambiguous symptom knowledge.

The cumulative number of risk factors for each respondent was calculatedand categorized as 'none', '13', or '4 or more' (Bolded by the researchers).

Categorizing the common verb types doesn't provide enough information to pinpoint the possible differences. Thus the verb types were counted and fed into SPSS v.16. Then Chi-square was run. The result is shown in table 3.

Table 3. Chi-square statistics for all verb types

\begin{tabular}{llll}
\hline & Value & $\mathrm{df}$ & Asymp. Sig. (2-sided) \\
\hline Pearson Chi-Square & $49.887^{\mathrm{a}}$ & 2 & .000 \\
Likelihood Ratio & 49.805 & 2 & .000 \\
Linear-by-Linear Association & 47.549 & 1 & .000 \\
N of Valid Cases & 10491 & & \\
\hline a. 0 cells (.0\%) have expected count less than 5. The minimum expected count is 455.96. \\
\hline
\end{tabular}

The figure in table 3 shows that there is a significant difference between types of verbs chosen in the scholarly articles written in English by native speakers and the non-native ones. In other words, since "P" value at 2 degree of freedom is smaller than 0.05 , the difference is significant.

However, chi-square doesn't show where exactly the differences lie. To locate the areas of differences, the data once again was fed into SPSS v16. Then the observed frequencies of the each type of verb were calculated. The summary of the data collected is shown in table 4 . 
Table 4. The observed frequencies of all variables

\begin{tabular}{llllll}
\hline & & \multicolumn{3}{l}{ Verb Type } & \multirow{2}{*}{ Total } \\
\cline { 3 - 5 } & & Material & Mental & Relational & \\
\hline \multirow{2}{*}{ English Language: } & The Natives & 3548 & 548 & 1573 & 5669 \\
& The Non-Natives & 2734 & 444 & 1644 & 4822 \\
\hline \multirow{2}{*}{ Total } & 6282 & 992 & 3217 & 10491 \\
\hline
\end{tabular}

The figures in table 2 indicate that native speakers use a larger portion of material and mental verbs. In contrast, non-native speakers only practice more relational verbs. To be able to pin point the area of differences, expected frequency is also required to be computed. Thus Crosstabulation was run. The expected verb frequencies are shown in table 5 .

Table 5. The expected frequencies of all variables

\begin{tabular}{llllll}
\hline & & \multicolumn{3}{l}{ Verb Type } & \multirow{2}{*}{ Total } \\
\cline { 3 - 5 } & & Material & Mental & Relational & \\
\hline \multirow{2}{*}{ English Language: } & The Natives & 3394.6 & 536.0 & 1738.4 & 5669.0 \\
& The Non-Natives & 2887.4 & 456.0 & 1478.6 & 4822.0 \\
\hline \multirow{2}{*}{ Total } & 6282.0 & 992.0 & 3217.0 & 10491.0 \\
\hline
\end{tabular}

The expected frequencies show the number of cases expected for each verb type. Through mapping the observed frequencies of the verbs and expected ones, the exact pattern of differences is highlighted.

As table 4 and 5 shows, the portion of material verbs (3548) chosen by native speakers is more than expected (3394.6). Like material verbs, native speakers choose mental verbs (548) more than expected (536) though the portion is not so large. On the other hand, only the frequency of relational verbs found in the articles by non-native speakers is higher than the expected one.

The major aim of the present study was to investigate whether or not there is any significant difference in choosing verb types as proposed by Halliday (1994) on the part of researchers while writing their papers in English. The statistical analysis (Chi-square) indicates that there is a significant difference between English native speakers and the non-native ones. The results show that the verbs' loading is different in the scholarly articles by English native and non-native speakers. In other words, some verbs are applied more than others.

To recognize where the difference lies, the frequencies (observed and expected) were taken into consideration. The results show that the portions of material and mental verbs chosen by English native speakers are larger than those of the non-native ones. The reason of it may be due to the knowledge which English native speakers have of the functions of language in general and experiential metafunctions in particular. In a better sense, being equipped with knowledge of the relationship between language functions and social aspects, the English native speakers can choose the verb type best suit their intended meaning. Moreover, as the readers seek for metafunctions to deepen and facilitate their own comprehension Bumela (2013), it is now a criterion to process articles in English by editorial board of scholarly journals.

The results also support the studies carried out earlier on different aspects of exploring the role of metafunctions. Having introduced the metafunction, Bumela (2013) reported a change in the comprehension performance of the students in ESP classes. Unlike his study, in the present study the final products of the researchers were analyzed to recognize the crucial role of experiential metafunction.

In addition, the findings also support a work by Amiryousefi and Eslami Rasekh (2010). They reported that it is through the application of metafunctions in writing and speaking that we negotiate with others and make desirable effects which we would like to have on our audiences. They conclude that having the knowledge of metafunctions can help us meet the norms of writing and speaking as well as the expectations of our intended audiences. Unlike their work, the areas of differences between two groups of researchers (English native and non-native speakers) were highlighted through analyzing their scholarly published works. 
Finally, the results go in line with a work by Talebzadeh et al. (2012). They in their study touched the role of metafunctions through determining the verb tense, voice, personal and no personal pronouns. They argue that the English native speakers differ from the non-native ones regarding the portion of verb tense, voice, personal and no personal pronouns employed. Like their study, the findings here show that the load of types of verbs is different in the works written in English by the English native and non-native speakers.

Based on the findings, meaning negotiation and meeting expectations of the readers can be achieved through using appropriate language functions.Choosing the right metafunctions seems to help researchers meet the conventions of the scholarly writing proposed by linguists Swales and Feak (2007). In other words, peer-reviewed international journals on medical sciences have developed their own framework based on such conventions. Thus their wide range of audiences wishing to publish their articles in them is required to follow such a framework.

\section{Conclusion and Implications}

The major aim of the present study was to investigate if there is any significant difference between types of verbs chosen by non-native English and native researchers. To this end, 80 articles written in English by native and non-native researchers were analyzed. Having run Chi-square, the results indicate that the scholarly articles written in English by native and non-native speakers have different loading of types of verbs.

The results show that non-native speakers tend to use more relational verbs while writing scholarly articles. On the other hand, native speakers choose material and mental verbs as they disseminating their scientific achievements through an article.

Pedagogically speaking, the findings of this study should deepen our understanding of the nature of scholarly article writing. Deciding on the appropriate metafunctions help non-native English researchers not only linguistically follow the model of scholarly writing, but also share their scientific achievement throughgetting their articles published in the journals indexed by international indexing databases. One reason that can explain the inability of many non-native English researchers to get their articles published is the different nature of various languages (Martin, 2003). In other words, the researchers are required to adapt the functional view as well (Halliday, 1985).

In addition, teachers, in ESP classes, should pay more attention to the types of verbs proposed by Halliday (1994). Furthermore, the ESP material developers had better design and/or adapt materials based on the findings of the present study. As Hutchinson and Waters (1987) and Thompson (1996) argue, including the structures and linguistic elements based on the functions best suit their field of study rather than those with less frequent structures in ESP textbooks and syllabus will ensure the relevance of the ESP course books to the students' needs. Likewise, it seemingly is the responsibility of the students to attend to common types of verbs to ensure that their original works are structurally and linguistically based on the accepted model of scholarly writing.

Hopefully, this study is just the beginning. Since any scientific research is not self-evident, it must be verified by observation and experimentation. In so doing, researchers may face some limitations. Hence, somewhat different results might have come to in this study if the following limitations were not confronted. First, since only 80 articles were analyzed in this study, the results should cautiously be generalized to other fields of studies. Second, the article selection was based on the researchers' accessibility. Random selection may bring about different results. Finally, different classifications of languages and sub-genres in any fields of study may lead to different results.

\section{References}

Amiryousefi, M., \& Rasekh, A. E. (2010). Metadiscourse: Definition, Issues and its Implications for English Teacchers. English Language Teaching, 3(4), 159-167.

Bilal, A. H. (2012). Analysis of Thanks M'am: Halliday's Metafunctions. Academic Research Journal, 2(1), 726-732.

Bloor, M., \& Bloor, T. (1995). The Functional Analysis of Engilsh. London: Arnold.

Bumela, L. (2013). Metafunctions Revealed: EFL Learners' Experience in Making Sense of the Text. Indonesian Journal of Applied Linguistics, 1(1), 106-119. http://dx.doi.org/10.2012\%2Fijal.v1i2.88

Chakorn, O. (2006). Persuasive and Politeness Strategies in Cross-Cultural Letters of Request in Thai Business

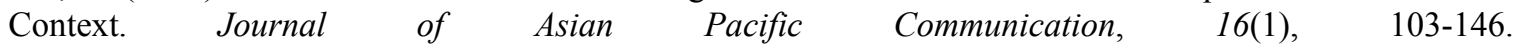
http://dx.doi.org/10.1075/japc.16.1.06cha 
Chakorn, O. (2007). The Positive Use of Visual Aids in Thai Annual Reports in Time of Crisis: Visual Literacy anf the Creation of Positive Meaning. Paper presented at the Visual Lieteracies-Exploring Critical Issues, Mansfield College.

Chakorn, O. (2011). Understanding Professional English Texts through Systemic Functional Linguistics: An Analysis of The metafunctions In Corporate Business Discourse. Retrieved February, 2014, from http://www.studymode.com/essays/Understanding-Professional-English-Texts-Through-Systemic-658628.h tml

Chomsky, N. (1972). Language and Mind. Harcourt Brace Jovanovich, Inc.

Chomsky, N. (1988). Language and Problems of Knowledge. Cambridge: MIT Press.

Connor, U. (1996). Contrastive Rhetoric: Cross-Cultural Aspects of Second Language Writing. Cambridge: CUP.

Dunmire, P. L. (2008). The Rhetoric of Temoprality: the Future as linguistic Construct and Rhretorical Resource. In B. Johnstone, \& C. Eisenhart (Eds.), Rhetoric in Detail: Discourse Analyses of Rhetorical Talk and Text. Philadelphia: John Benjamines.

Fleischman, S. (2003). Language and Medicine. In D. Schiffrin, D. Tannen, \& H. E. Hamilton (Eds.), The Handbook of Discourse Analysis. Oxford: Blackwell Pubblishing.

Fuzer, C., \& Barros, N. C. (2009). Accusation and Defense: The Ideational Metafunction of Language in the Genre Closing Argument. In C. Bazerman, A. Bonini, \& D. Figueiredo (Eds.), Genre in a Changing World. Colorado: WAC Clearing House.

Givon, T. (1995). Functionalism and Grammar. Amesterdam: John Benjamins.

Halliday, M. (1985). An Introduction to Funcational Grammar. London: Arnold.

Halliday, M. (1994). An Introduction to Functional Grammar (2nd ed.). London: Edward Arnold.

Halliday, M. (2003). Meaning and the Consstruction of Reality in Early Childhood. In M. Halliday (Ed.), The Language of Early Childhood (pp. 113-152). UK: MPG Books, Ltd.

Halliday, M., \& Matthiessen, C. M. I. M. (2004). An Introduction to Functional Grammar (3rd ed.). London: Hodder Arnold.

Helan, R., \& Jitka, V. (2012). Analysis of Pubblished Medical Case Report: Genre-based Study (Unpublished PhD dissertation). Masaryk University. Czech Republic.

Hutchinson, T., \& Waters, A. (1987). English for Specific Purposes. Campridge: CPU.

Jalilfar, A. R. (2010). The Status of Theme in Appied Linguistics Articles. The Asian ESP Journal, 6(2), 7-39.

Jones, C. L. (2005). The value of a Systemic Functional Approach to ESP or rather LSP. Studies About Languages, 7, 5-11.

Kanoksilapatham, B. (2007). Writing Scientific Research Articles in Thai and English: Similarities and Differences. Sitpakorn University International Journal, 7, 172-203.

Martin, J. (1992). English Text: System and Structure. PA: John Benjamins.

Martin, P. (2003). A Genre Analysis of English and Spanish Research Paper Abstract in Experimental Social Sciences. English for Specific Purposes, 22(1), 25-43. http://dx.doi.org/10.1016/S0889-4906(01)00033-3

Nwogu, K. N. (1997). The Medical Research Paper: Structure and Functions. English for Specific Purposes, 16(2), 119-138. http://dx.doi.org/10.1016/S0889-4906(97)85388-4

Pandian, A., \& Assadi, N. (2010). ABC's of Functional Grammar. Selengor Darul Ehsan: Oxford Fajar.

Pishghadam, R. (2010). The Analysis of ESP Textbooks in the Light of Halliday's Systemic Functional Grammar. In G. Tchibozo (Ed.), The 2nd Paris International Conference on Education, Economy and Society (Vol. 3, pp. 151-157). Strasbourg (France): ANALYTRICS.

Swales, M. J., \& Feak, B. C. (2007). Academic Writing for Graduate Students (2nd ed.). Ann Arbor: University of Michigan Press.

Talebzadeh, M., Arabi, Z., Taki, S., \& Akhlaghi, M. (2012). Rhetorical Variation in Medical Article Abstract Written in English and Persian. The Journal of English Language Teaching, 3(4), 127-144.

Thompson, G. (1996). Introduction to Functional Grammar. London: Arnold. 


\section{Copyrights}

Copyright for this article is retained by the author(s), with first publication rights granted to the journal.

This is an open-access article distributed under the terms and conditions of the Creative Commons Attribution license (http://creativecommons.org/licenses/by/3.0/). 